Nova Biologica Reperta 7(4): 453-456 (2021)

Print ISSN: 2423-6330/Online ISSN: 2476-7115

https://nbr.khu.ac.ir; Kharazmi University Press; DOI: 10.29252/nbr.7.4.453

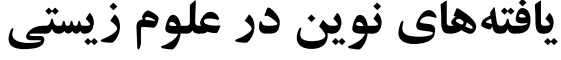

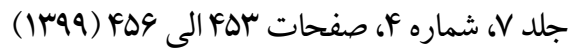

انتشارات دانشگاه خوارزمى

$$
\begin{aligned}
& \text { Fونه Onosma sulaimanica (تيره Fاوزبانيان) به عنوان گزارشى جديد براى فلور ايران }
\end{aligned}
$$

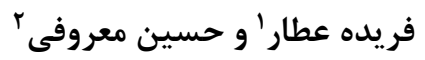

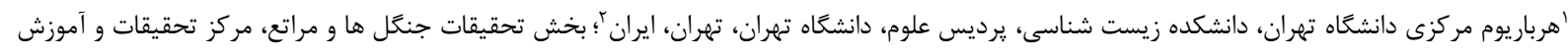

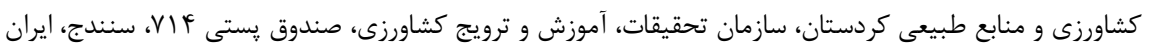

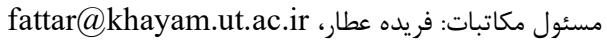

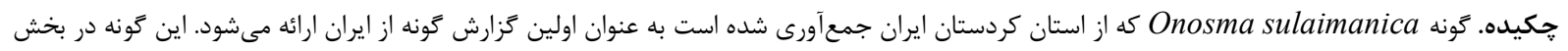

بnosma

$$
\text { يكديكر هستند به همراه تصاوير و نقشه يراكنش ارائه مى نشوند. }
$$$$
\text { وازمهاى كليدى. بخش اونوسما، خاورميانه، زيربخش اونوسما، شاهو،كردستان }
$$

\title{
Onosma sulaimanica (Boraginaceae), a new record for the flora of Iran
}

\section{Farideh Attar $^{1}$ \& Hossein Maroofi ${ }^{2}$}

${ }^{1}$ Central Herbarium of Tehran University, School of Biology, College of Science, University of Tehran, P. O. Box 14155-6455, Tehran, Iran; ${ }^{2}$ Forests and Rangelands Research Department, Kurdistan Agricultural and Natural Resources Research and Education Center, AREEO (Agricultural Research, Education \& Extension Organization), P. O. Box 714, Sanandaj, Iran

Correspondent author: Farideh Attar, fattar@khayam.ut.ac.ir

\begin{abstract}
In this article the collection of specimens related to Onosma sulaimanica from Kordestan Province, Iran, was confirmed and reported for the first time. Therefore, the species is recorded for the flora of Iran. This species is placed in the sect. Onosma, subsect. Onosma, ser. Wheeler-hainesii. A diagnostic key of related taxa belonging to series Wheeler-Hainesii and Aleppica, and the photos, micrographs and a distribution map of the species were also presented.
\end{abstract}

Keywords. Kordestan, Middle East, section Onosma, Shahu, subsection Onosma 


\section{INTRODUCTION}

Onosma L. is a species-rich genus (Boraginaceae, tribe Lithospermeae) and includes about 170 species all around the world (Naqinezhad \& Attar, 2016; Cecchi \& Selvi, 2009; Kolarčik et al., 2010). The genus is distributed across Europe to East Asia and is especially well-distributed in Western and Central Asia, the Mediterranean area, Anatolia and Southeast Europe (Kolarčik et al., 2010). Iran, Turkey (Anatolia) and Central Asia are the diversity centers of the genus Onosma (Tiwari et al., 2011). Onosma species grow in xeric, dry, cliffy, sunny, rocky, sandy and steppe habitats (Peruzzi \& Passalacqua, 2004).

Riedl (1967) recognized three sections for genus Onosma in Flora Iranica: Protonosma Popov (O. rostellata Lehm.), Podonosma (Boiss.) Gurcke ( $O$. orientalis L.) and Onosma with two subsections: Onosma (with about 50 taxa) and Asterotricha (Boiss.) Gurke (with about 14 taxa). Onosma orientalis has changed to Podonosma orientalis (L.) Feinbrun now. Genus Onosma contains about 60 species in Flora Iranica region based on Riedl's work (Riedl, 1967).

After the publication of Flora Iranica treatment of the genus (Riedl, 1967), Ponert (1973) and Teppner (1980) described O. kurdica and O. sabalanica from Kordestan and Azarbayejan Provinces, respectively. In recent years, some new species were described from Iran: Onosma iranshahrii Ghahr. \& Attar (Ghahreman \& Attar, 1996), O. bisotunensis Attar \& Hamzeh'ee (Attar \& Hamzeh'ee, 2007), $O$. khorasanica Attar \& Joharchi (Attar \& Joharchi, 2006), O. ghahremanii Attar \& Naqinezhad (Naqinezhad \& Attar 2016), O. mozaffarianii Mehrabian (Mehrabian et al., 2013), $O$. estahbanensis Ranjbar \& Almasi, O. mahabadensis Ranjbar \& Almasi and O. maculata Ranjbar \& Almasi (Ranjbar \& Almasi, 2013, 2014, 2015), O. targevarensis Mozaff. \& Mehrabian, $O$. sarvestanica Mozaff. \& Mehrabian (Mehrabian \& Mozaffarian, 2018), O. zagrica Dehshiri (Dehshiri, 2018). Therefore, the number of Onosma species in the flora of Iran increased to 64 .

The most important characters for delimiting of species are found to be indumentum type of lower leaves, inflorescence shape, bract shape, corolla length and its changing color, indumentum of corolla's outside, anther and filament length and hairy or glabrous nectariferous annulus (Riedl, 1967).

\section{MATERIALS AND METHODS}

During the study of genus Onosma related specimens stored in the herbarium of Kordestan Agricultural and Natural Resources Research and Education Center (HKS) were examined. Among them some interesting specimens belong flora of Iraq were found which previously not reported from Iran. For determine of specimens we used some literature resources such as Flora of Iran (Parsa, 1949), Flora Iranica (Riedl, 1967) and Flora of Iran (Khatamsaz, 2002). Moreover, specimens studied were compared to the pictures of type specimens. Indumentum of the specimens was photographed by a Dino-Lite digital microscope AM413T and the measurement was done by means of the integrated software of the device. The specimens were photographed with a Canon PowerShot SX260 HS camera.

\section{RESULTS}

During floristic investigations in W Iran, Kordestan Province, some interesting specimens were collected. Based on Flora Iranica treatment for the genus (Riedl, 1967), these specimens were determined as Onosma sulaimanica Riedl that is a new record for the flora of Iran. Therefore, the total number of taxa within the genus Onosma in Iran reached to 65 taxa by the addition of this reported species. According to Riedl (1967), Onosma sulaimanica belongs to sect. Onosma, subsect. Onosma, series Wheeler-hainesii. The most diagnostic characters of series Wheeler-hainesii including: annulus densely hairy, calyx with 5 linear free segments, anthers free along length (Riedl, 1967). Series Wheeler-hainesii Riedl belongs to series Aleppica Riedl considering their habit, hairy nectariferous annulus, anther and filament length, free calyx lobes, corolla color and indumentum type of lower leaves.

Onosma sulaimanica Riedl, Flora Iranica, vol. 48: 190 (1967). Figs. 1-3.

Perennial, up to $30 \mathrm{~cm}$ tall. Stem branched, patent white setose. Lower and median leaves 35-80 $\times 5$ $10 \mathrm{~mm}$, lorate-lanceolate; margin revolute; indumentum consists of patent-adpressed setae with glabrous tubercles, between setae sparsely pubescent. Cymes a compact scorpioid, with lateral branches, few-flowered, to $30 \mathrm{~mm}$ in diam.; lower bracts to $20 \times 5 \mathrm{~mm}$; pedicels up to $5 \mathrm{~mm}$ long; flowering calyx 14-17 mm; corolla yellowish white, 17-20 $\mathrm{mm}$ long, clavate-campanulate, outside papillose; lobes $4.5 \times 3.5 \mathrm{~mm}$; filaments $8 \mathrm{~mm}$ long; adnate to $6 \mathrm{~mm}$ above corolla base; anthers $6-7 \mathrm{~mm}$ long; annulus densely hairy. Nutlets not seen.

Examined specimens: Iran. Kordestan Province: Saqqez, Kanijegeni, 1450 m, 11.6.2004, Maroofi \& Fani 6831 (HKS!); southern west of Sanandaj, Shahu area, Esparez village, 1150 m, Kaffash 3080 

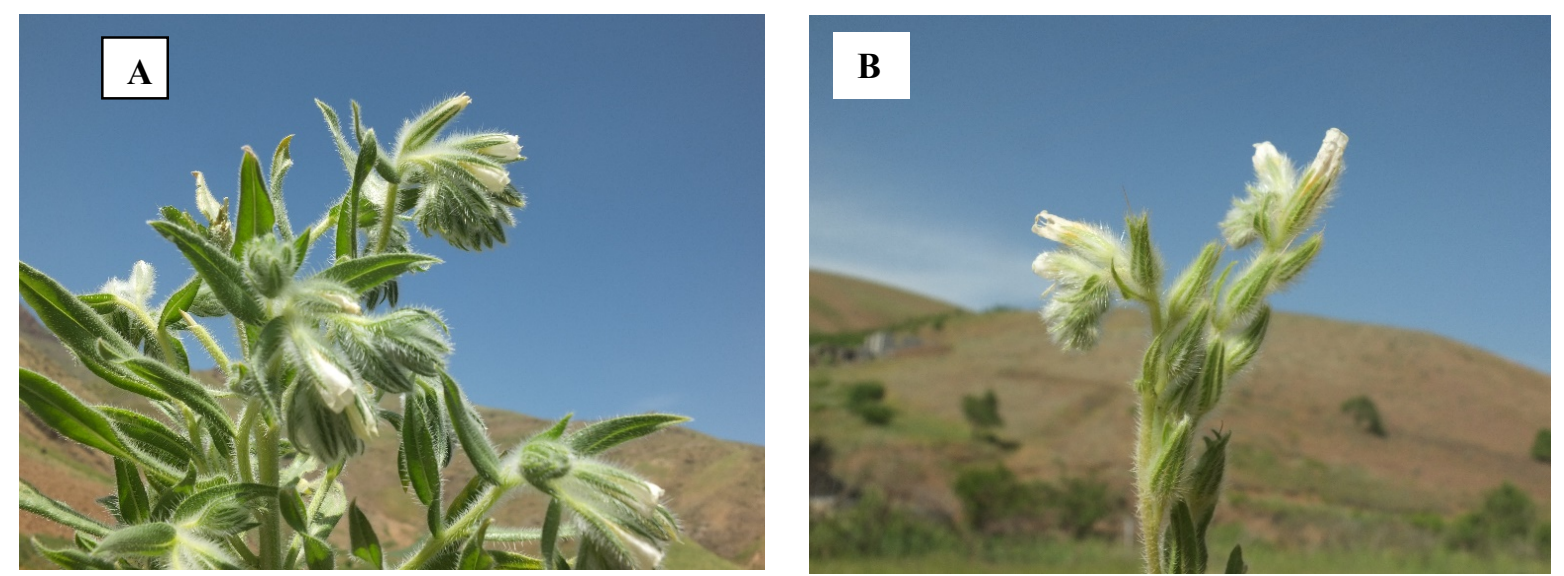

Figure 1. A. Onosma sulaimanica and B. Onosma bulbotricha. A part of inflorescence showing bract, calyx and corolla.
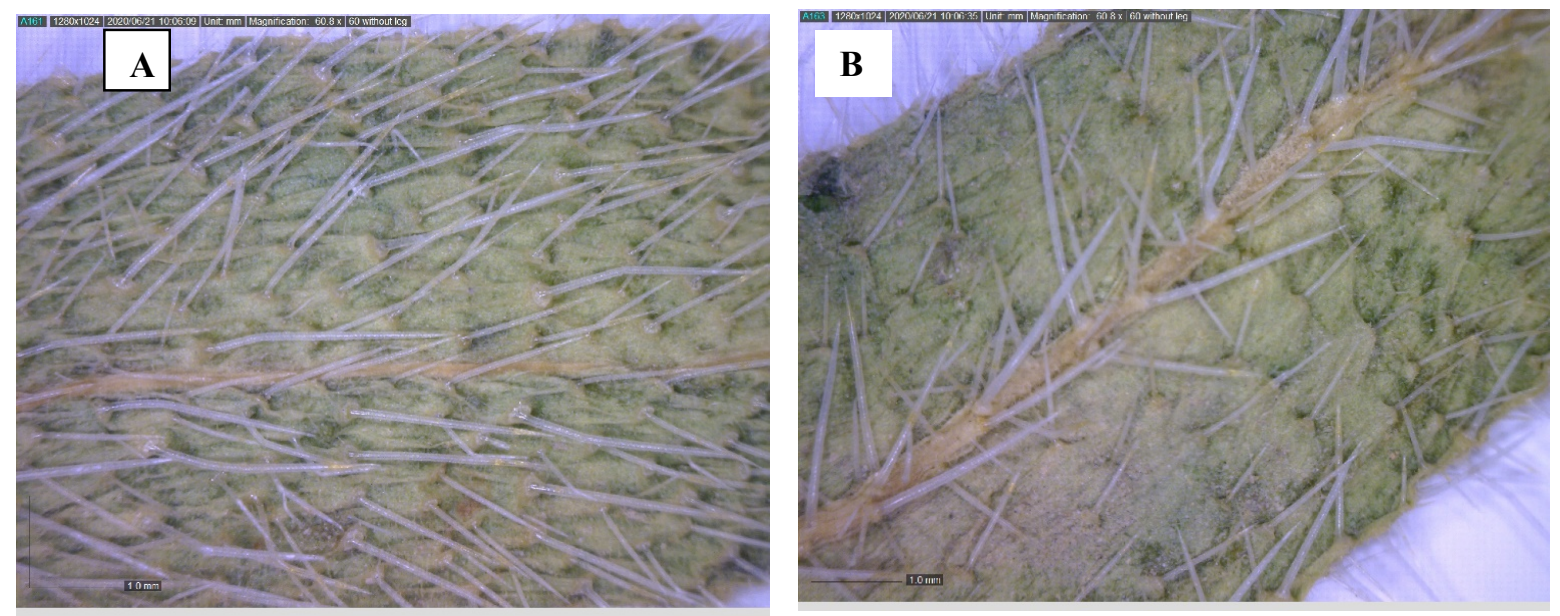

Figure 2. Onosma sulaimanica: A. upper surface, B. lower surface, showing adpressed tubercled setae.

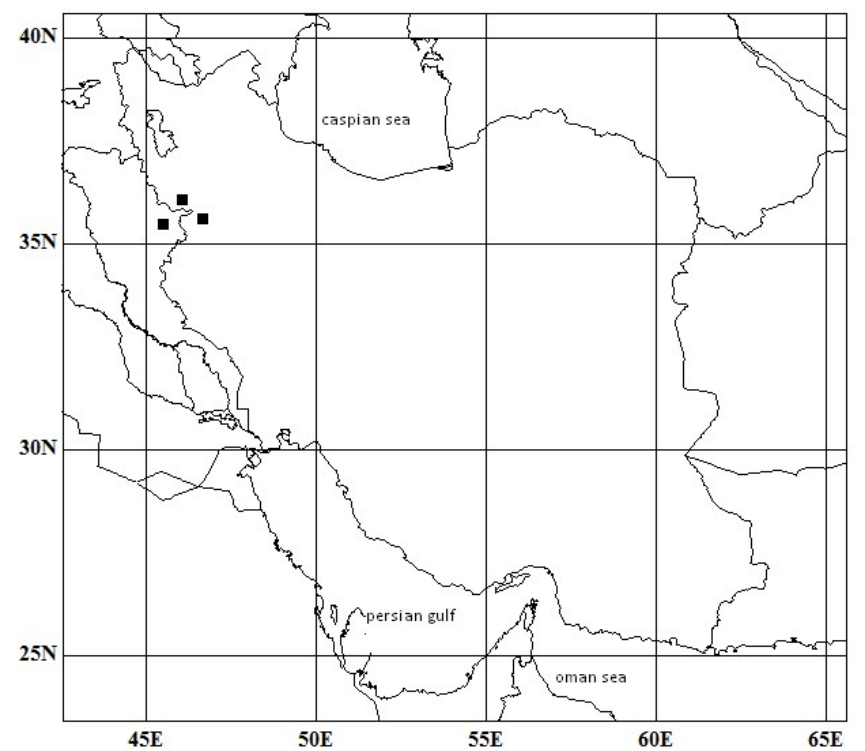

Figure 3. Distribution map of Onosma sulaimanica. 
(HKS!); above Avihang village, $2111 \mathrm{~m}$, 27.05.2019, Attar, Asgari, Bahadori, Advay 48480 (TUH!).

Onosma solaimanica is close to O. bulbotricha DC. and O. cyrenaica Durand \& Barr. var. strausii Riedl. Based on their habit, indumentum type of lower leaves, stamen status, hairy annulus nectariferous. Considering their similarities, a diagnostic key is presented for delimiting of species.

Diagnostic key of taxa of series Wheeler-Hainesii Riedl and Aleppica Riedl in Iran

1. Corolla pink; pedicel up to $9 \mathrm{~mm}$ long.................... O. cyrenaica var. straussii -Corolla white or yellowish-white ................ 2 2. Flowering calyx 14-16 mm long; corolla's outside papillose; corolla lobes $4.5 \mathrm{~mm}$ width at bas................................ O. sulaimanica -Flowering calyx 15-20 mm long; corolla's outside glabrous or pubescent, corolla lobes narrower at base O. bulbotricha

\section{ACKNOWLEDGEMENT}

The authors thank the anonymous reviewers for their valuable comments.

\section{REFERENCES}

Attar, F. \& Joharchi, M.R. 2006. Onosma khorassanica, a new species from Northeast of Iran. Rostaniha 7 (Suppl. 2): 111-114.

Attar, F. \& Hamzehee, B. 2007. Onosma bisotunensis (Boraginaceae), a new species from Western Iran. Novon 17: 279-281.

Cecchi, L. \& Selvi, F. 2009. Phylogenetic relationships of the monotypic genera Halascya and Paramoltkia and the origins of serpentine adaptation in circummediterranean Lithospermeae (Boraginaceae): insights from ITS and matK DNA sequences. Taxon 58: 700-714.

Dehshiri, M. M. 2018. Onosma zagrica (Boraginaceae), a new species from Iran. Phytotaxa 367: 284-290.

Ghahreman, A. \& Attar, F. 1996. A new species of the genus Onosma from W. Iran. Iranian Journal of Botany 7: 51-55.
Khatamsaz, M. 2002. Boraginaceae. In: Flora of Iran. Assadi et al. (eds.), Vol. 39. Research Institute of Forests and Rangelands, Tehran.

Kolarčik, V., Zozomová-Lihová, J. \& Mártonfi, P. 2010. Systematics and evolutionary history of the Asterotricha group of the genus Onosma (Boraginaceae) in central and southern Europe inferred from AFLP and nrDNA ITS data. Plant Systematics and Evolution 290: 21-45.

Mehrabian, A.R., Sheidai, M. \& Mozaffarian, V. 2013. Three new species of Onosma (Boraginaceae) in Iran. Feddes Repertorium 124: 69-79.

Mehrabian, A. R. \& Mozaffarian, V. 2018. Seven new species of Onosma L. (Boraginaceae) with emphasis on their habitats in Iran. Taiwania 63: 366-388.

Naqinezhad, A. \& Attar, F. 2016. Onosma ghahremanii sp. nov. (Boraginaceae), a new species from Alborz Mts., Iran. Phytotaxa 268: 286-290.

Parsa, A. 1949. Flore de l'Iran, Teheran, vol. 4: 101-214.

Peruzzi, L. \& Passalacqua, N. G. 2004. Problematiche relative al gruppo Onosma echioides (L.) L. (Boraginaceae) in Italia. Informatore Botanico Italiano 36: 162-164.

Ponert, J. 1973 A new species of Onosma from Iran. Preslia 45: 140-141.

Ranjbar, M. \& Almasi, M. 2013. Cytotaxonomic revision of Onosma series Aleppica (Boraginaceae) in Iran. Biological Diversity and Conservation 6: 1-15.

Ranjbar, M. \& Almasi, M. 2014. Taxonomic notes on Onosma sect. Aponosma from Iran (Boraginaceae). Edinburgh Journal of Botany 71: 75-82.

Ranjbar, M. and Almasi, M. 2015. Onosma maculata (Boraginaceae), a remarkable new species from Iran. Nordic Journal of Botany 33: 522-525.

Riedl, H. 1967. Onosma. pp. 169-212. In: Rechinger, K.H. (ed.), Flora Iranica, Vol. 48. Akademische Druck-u. Verlagsanstalt, Graz, Austria.

Teppner, H. 1980. Onosma kurdicum Teppner: a new species from Iran. Phyton 20: 141-145.

Tiwari, U.K.L., Adhikari, B.S. \& Rawat, G.S. 2011. On the recollection and rediscovery of Onosma pyramidale Hook.f., Boraginaceae from Chamoli, Uttarakhand. Asian Journal of Pharmacy \& Life Science 1: 406-408.

How to cite this article:

Attar, F. \& Maroofi, H. 2021. Onosma sulaimanica (Boraginaceae), a new record for the flora of Iran. Nova Biologica Reperta 7: 453-456. 